\title{
Psychoeducational Group Curriculum to Address American Indian Marginalization
}

\author{
Jesse A. Steinfeldt ${ }^{1}$, Brad D. Foltz², Rex A. Stockton ${ }^{1}$ \\ ${ }^{1}$ Indiana University, Bloomington, USA \\ ${ }^{2}$ Southern Illinois University, Edwardsville, USA \\ Email: jesstein@indiana.edu
}

Received 12 August 2014; revised 8 September 2014; accepted 30 September 2014

Academic Editor: Stavroula A. Papadodima, University of Athens, Greece

Copyright (C) 2014 by authors and Scientific Research Publishing Inc.

This work is licensed under the Creative Commons Attribution International License (CC BY). http://creativecommons.org/licenses/by/4.0/

c) (i) Open Access

\section{Abstract}

As a mechanism for collaborative group learning, we have designed a psychoeducational group curriculum that utilizes social justice principles within a liberation framework to address societal marginalization of American Indian communities. The curriculum within this proposed psychoeducational group format helps educators facilitate student exploration of societal portrayals of American Indians with the intent of developing action plans to address social injustice. Students exposed to the curriculum within this psychoeducational group will be equipped with critical thinking skills to transform their emerging social justice awareness and knowledge into social justice skills. Additionally, educators who lead this group can become social justice role models for others by using this experience to address issues of oppression and marginalization that are manifest in other forms in society.

\section{Keywords}

Stereotypes, Native-Themed Mascots, Nicknames, and Logos, American Indians, Marginalization Psychoeducational Group Counseling

\section{Introduction}

Social justice and advocacy issues have emerged as prominent themes within counseling psychology and education within recent times (Aldarondo, 2007). Counselors, psychologists, and educators who operate within social justice paradigms, "strive to intentionally ameliorate social injustices that adversely affect the mental health of larger numbers of persons in oppressed and marginalized groups in contemporary society” (Crethar, Torres Rivera, \& Nash, 2008: p. 269). Relative to other racial groups in the United States, American Indian communities 
face serious mental health issues, including disproportionately high rates of suicide, anxiety, depression, and substance abuse (IHS, 2011; Olson \& Wahab, 2006). Examining how the societal marginalization of American Indians contributes to these disproportionate mental health outcomes can help better understand and eventually address this nefarious dynamic. And doing so can help both educators and students become advocates of change-responsible citizens who are committed to addressing social injustices, particularly the widespread societal marginalization and appropriation of American Indian culture.

This manuscript presents a curriculum that can be delivered within a psychoeducational group format that educators can use to teach students social justice skills that will not only provide awareness into a social injustice, but it will also increase students' collaborative engagement skills as they expand their abilities to relate to people different from themselves. We purport that a psychoeducational group format utilizing social justice principles within a liberation framework represents a potentially effective way for students to critically examine the systemic marginalization of American Indians in society. The psychoeducational group format, which is congruent with the educational experiences facilitated by the school setting, allows for both the didactic presentation of content and the collaborative opportunity for group members to process the relationship between members in addition to the content (Stockton, Terry, \& Bhusumane, 2007). Although this proposed group has a single-issue focus (i.e., American Indian marginalization), students can use this experience to develop critical thinking skills to better understand instances of societal injustice perpetuated on other groups (e.g., American Muslims, Latino residents of Arizona). Students and group leaders can create opportunities to "notice how different issues intersect in order to help participants understand the many parallels and connections among different forms of oppression” (Bell \& Griffin, 2007: p. 68). Thus, participants exposed to the curriculum in this psychoeducational group can use this exploration of American Indian marginalization to further examine aspects of oppression and marginalization that are personally and professionally relevant to them.

\section{Social Justice and Liberation Perspective}

Despite the emergent emphasis on social justice, varying definitions of this construct exist (Pieterse, Evans, Risner-Butner, Collins, \& Mason, 2009). Goodman et al. (2004) offer a broadly accepted definition of social justice by defining it as, "the scholarship and professional action designed to change societal values, structures, policies, and practices, such that disadvantaged or marginalized groups gain increased access to these tools of self-determination” (p. 795). From this perspective, an emphasis on social justice can lead to personal and professional worldviews that align with the belief that educators, "should have a professional bias in favor of significant social change” (Fox, 1993: p. 239). Thus, including multiculturalism and social justice into one's repertoire becomes more than a professional obligation (APA, 2003, 2005, 2008)—it becomes a desired moral imperative (e.g., Duran, Firehammer, \& Gonzalez, 2008; Vera \& Speight, 2003).

In order to effectively identify and combat systemic forms of oppression, social justice-oriented educators must develop a sense of critical consciousness (Duran et al., 2008; Freire, 1970; Goodman et al., 2004; Goodman \& West-Olatunji, 2009). A social justice orientation within a liberation psychology framework can effectively cultivate the consciousness necessary to understand the experiences of marginalized populations, particularly groups that have faced and continue to face psychological oppression (Duran et al., 2008). Duran (2006) describes the need for this perspective by saying.

Liberation discourse involves taking a crucial eye to the processes of colonization that have had a deep impact on the identity of Original Peoples; as a result, a new narrative of healing will emerge. The mental health profession has been instrumental in fostering the colonial ideation of Native Peoples all over the world... By turning a critical eye on our professional activities of healing, we liberate ourselves as well (p. 1).

A liberation perspective within social justice is particularly useful in conceptualizing the position of American Indian communities within mainstream American society because of the pervasive marginalization of American Indian culture. The mechanisms of this marginalization are embedded within societal institutions, both in American society in general and within our mental health fields. "Because the counseling profession has, in large part, held a privileged position in the United States, many counselors have been unaware of and complacent to many forms of societal injustice that continue to be perpetuated in marginalized communities” (Duran et al., 2008: p. 289). Thus, educators and mental health professionals need to cultivate a sense of critical consciousness within this liberation perspective of social justice in order to effectively advocate for change on behalf of groups who face ongoing marginalization. 


\section{Mechanisms of American Indian Marginalization}

For American Indian communities, this oppressive marginalization process occurs in many forms and contributes to disparate health and mental health outcomes (Alkon \& Norgaard, 2009; Indian Health Services [IHS], 2009; Olson \& Wahab, 2006).The mechanisms of institutional marginalization of American Indians are present in number of institutions in our society. For example, American history textbooks are filled with widespread misinformation about American Indians (Loewen, 2008). Subsequently, even well-intentioned educators are miseducating and misleading students, who in turn continue to perpetuate stereotypes about American Indians. According to Loewen, "Historically, American Indians have been the most lied-about subset of our population" (2008, p. 93). Subsequently, educational curriculum needs to be adjusted to not only learn about American Indians, but to also unlearn misrepresentations about American Indian culture that permeate current educational curriculum.

One of the most prominent mechanism of perpetuating societal stereotypes and misinformation about American Indians is the oft-overlooked yet omnipresent practice of using American Indian names and imagery in sports (King, Davis-Delano, Staurowsky, \& Baca, 2006). Sports-related representations of American Indians (e.g., Redskins, Braves, Indians) can be considered harmful because they: 1) misuse cultural practices and sacred symbols; 2) perpetuate racist stereotypes of American Indians (e.g., the noble savage, the bloodthirsty savage, a historic race that only exists in past-tense status, one singular pan-Indian culture); 3) deny American Indians control over societal definitions of themselves; and 4) create a racially hostile environment for all students (Fenelon, 1999; King, Staurowsky, Baca, Davis, \& Pewewardy, 2002; Pewewardy, 1991; Russel, 2003; Staurowsky, 2004; Williams, 2007). The American Counseling Association (ACA) produced a resolution in 2001 acknowledging that sports symbols and mascots that use American Indian imagery create a hostile environment for American Indians. The ACA resolution pledged to disseminate educational materials that highlight negative consequences of this practice, and encouraged members to work toward eliminating stereotypic American Indian images in institutions where they work (ACA, 2001). Over 120 other prominent professional organizations (e.g., American Psychological Association, US Commission on Civil Rights, Society of Indian Psychologists; American Indian Sports Team Mascots [AISTM], 2014) have produced similar resolutions calling for the immediate retirement of these harmful mechanisms of oppression and misinformation about American Indians.

Emerging psychological research has provided empirical data that supports these resolutions. Fryberg, Markus, Oyserman, \& Stone (2008) reported that, when exposed to Native-themed mascots, American Indian students reported significantly higher levels of depressed state self-esteem, lower levels of community worth, and fewer achievement related possible selves. The authors suggested that these stereotypic images remind American Indians of the narrow view society has of them, which threatens their psychological functioning and limits the possibilities they see for themselves (Fryberg et al., 2008). In another study, Steinfeldt \& Wong (2010) found that awareness of the offensiveness of Native-themed mascots, nicknames, and logos was significantly inversely related to color-blind racial attitudes (CoBRAs; Neville, Lilly, Duran, Lee, \& Browne, 2000). That is, the more awareness that a person has concerning the negative implications surrounding Native-themed mascots, nicknames, and logos, the greater awareness they have about racism in society (i.e., lower colorblind racial attitudes). A lack of awareness of racism in society can contribute to the belief that Native-themed mascots, nicknames, and logos honor American Indians (Steinfeldt et al., 2010). This belief can serve as an ego defense to help preserve a sense of racial egalitarianism, which simultaneously conceals the genocidal acts of European Americans toward American Indian communities (Grounds, 2001). Rather than address the occurrence of this genocidal past (e.g., Loewen, 2008), this ego defense creates the (mis)perception of some sort of contemporary unity between American Indians and members of mainstream society in the practice of using American Indian culture and imagery in sport, and color-blind racial attitudes may serve as the glue that binds this false union (Steinfeldt \& Wong, 2010).

Kim-Prieto, Goldstein, Okazaki, \& Kirschner (2010) examined Native-themed sports logos (e.g. those depicting American Indians as bloodthirsty savage warriors) in order to determine if these images increased stereotyping of another racial group (e.g., Asian Americans as socially inept). Results confirmed that the stereotypic representations provided by Native-themed mascots, nicknames, and logos increased the likelihood that people would endorse stereotypes of other groups, even when the stereotypes are different. Subsequently, the use of these race-based sports logos facilitates the process of stereotyping, contributing to a racially hostile environment (Kim-Prieto et al., 2010). In another study found in the psychological literature, Steinfeldt et al. (2010) 
analyzed 1700 newspaper online forums within a community with a Native-themed sports nickname and logo (i.e., Fighting Sioux). The results of their analysis indicated that a critical mass of online forum comments demonstrated ignorance about American Indian culture and disdain toward American Indians by perpetuating stereotypes, providing misinformation, and expressing overtly racist attitudes toward American Indians. Thus, the presence of a Native-themed nickname and logo facilitates an environment which can threaten the psychological functioning of American Indians by providing misinformation, by activating stereotypic representations, and by facilitating the expression of explicitly racist attitudes toward American Indians (Steinfeldt et al., 2010).

The empirical results of these scientific studies-when combined with the resolutions of these numerous prominent professional organizations (e.g., AISTM, 2014)—indicate that the misappropriation of American Indian culture facilitated by these stereotypic portrayals can contribute to the negative psychological functioning of American Indians. However, these stereotypic representations of American Indians are widely disseminated through numerous institutions in society (e.g., schools, media, athletic events), further compounding the difficulty in effectively addressing this issue. The omnipresence of these (and other) stereotypic images of American Indians in society (Merskin, 2001) creates the impression that the practice of appropriating American Indian imagery and culture for use in sporting events and commercial endeavors must be acceptable (King et al., 2006). This institutional mechanism creates a hegemonic effect that largely disallows a dialogue about the possibility that state-sanctioned practices (e.g., Columbus Day celebrations, public school sport teams with the nickname of Indians) could be considered racist, offensive, or harmful. Because the collaborative group learning process can be a transformative experience, rather than a perpetuation of oppressive societal dynamics, this curriculum can potentially effective in directly addressing this difficult topic. According to MacNair-Semands (2007), "social justice is a dynamic issue which inevitably surfaces whenever people from diverse backgrounds meet in groups" (p. 62). Thus, educators have the opportunity to use the collaborative group process to facilitate healing experiences, rather than be complicit in allowing potentially damaging interactions to occur that fuel the perpetuation of oppression (MacNair-Semands, 2007).

\section{Psycheducational Group Curriculum to Address American Indian Marginalization}

While this manuscript has been written for use with middle-school-aged children, the principles of this group format can be adapted more generally to other marginalized populations (e.g., LGBT, religious minorities, racial minorities) and used with various age groups. The skills underlying social justice advocacy need to be socially constructed in a developmental manner, and the group experience may represent the first time adolescents are able to collaboratively discuss and process social justice issues with their classmates. This powerful process can lead to significant attitudinal change. Thus, adolescents who become more aware of their own values during a group experience may feel more empowered to address social justice issues such as prejudice, discrimination, and oppression (Portman \& Portman, 2002). The overarching goal of this group is to provide a forum for students to begin their journey of unlearning racism and equipping themselves with the tools to be agents of change. The proposed psychoeducational group is intended for all students, but it may be of greatest benefit to students from mainstream American culture, including but not limited to White American students. Many social injustices are unintentionally perpetuated by otherwise well-intentioned individuals in society (Bell \& Griffin, 2007). Consciousness raising "involves a 'process of transformative learning' that awakens personal awareness, leads to critical self-reflection and analysis, discovers group commonality among a 'class' of situations" (Adams, 2007: p. 27). By attempting to raise consciousness and change attitudes (particularly among members of the mainstream culture), this proposed group has the potential to provide students with "knowledge [that] may empower them to recognize, identify, and positively change injustices as they begin to be advocates for social change in the $21^{\text {st }}$ century" (Portman \& Portman, 2002: p. 18).

Central to the success of this proposed psychoeducational group is the role of the leader or leaders. "Group facilitators who are unaware of their social privileges are particularly vulnerable to perpetuating the oppression of members from marginalized groups” (Smith \& Shin, 2008: p. 359). Thus, as role models to students, multiculturally competent educators need to possess knowledge of the life experiences, cultural heritage, and historical background of people who are culturally different (AMCD, 2009), particularly those who face ongoing marginalization in our society. Leaders interested in implementing the curriculum of this proposed psychoeducational group format should first engage in critical self-inquiry about their knowledge, awareness, and skills as it 
relates to issues salient to American Indian culture. For example, many tribes have a cultural heritage preservation component (informal or formal), so educators can take this opportunity to reach out to members of the American Indian community to educate themselves.

In addition to the necessary multicultural competence of the potential leaders, it is important to acknowledge the process of receiving support from a school's administration and/or surrounding community for social justice-themed groups. Introducing social injustice to students may be perceived as controversial, and "controversy is not something schools handle well” (Westheimer \& Kahne, 1998: p. 19). Thus, it is important to build relationships and coalitions with administrators, teachers, and community members. Receiving institutional support for implementing a social justice-themed group may require educators to utilize this relational capital in order to engage in sustained efforts to educate the school community on the value of the topic at hand. However, the topic of American Indian marginalization is gaining increased attention in society, particularly among young students within classroom settings. Emerging stories, such as one in which fourth-grade students dressed up as characters from the $15^{\text {th }}$ Century, and conducted a mock trial of Christopher Columbus, are becoming more commonplace. In this particular instance, the jury of students found Columbus guilty of thievery and of misrepresenting the Spanish crown, and they sentenced him to life in prison (Associated Press, 2009). Along these lines, one idea to increase the school community's amenability to our proposed topic may be to plan this group to begin in October (i.e., around Columbus Day) and continue throughout the celebration of National American Indian and Alaska Native Heritage month in November. Additionally, this group could be implemented in coordination with a social studies curriculum unit on social justice. Although educators, particularly counselors and psychologists, have "a moral and ethical responsibility to advocate for students and serve as agents for social and political change” (Ratts, DeKruyf, \& Chen-Hayes, 2007: p. 90), these educators need to be conscientious of the social climate in the context in which they operate.

The proposed psychoeducational group format involves four phases and represents a synthesis of aspects of the Empowering Students for Social Justice Model (Portman \& Portman, 2002) within the framework of the Liberation Model (Steele, 2008). Both of these models have been introduced in the counseling literature, and both illuminate social justice advocacy principles that can be facilitated by the group process. Table 1 illustrates how our proposed psychoeducational group can be structured. Each of the four phases has two sessions, with specific goals and content in each phase. Group dynamics relevant to each phase are also addressed, and examples of activities that can facilitate the process will be explained in detail in the sections that follow.

\subsection{Phase I: Investigation and Examination of Social Justice Principles}

In the first phase of this group, Investigation and examination of social justice principles, leaders should focus on educating students about setting norms to create a safe environment to start discussing difficult social justice issues, as well as conveying information about social justice principles (whether introduced for the first time or connected to a social studies curriculum on social justice). The two sessions in this phase, entitled Beginnings and Knowledge, serve to build a foundation and create a framework for students to begin to make sense of how they are internalizing societal representations of American Indians. In these sessions, group leaders can utilize Adams' (2007) framework for implementing social justice principles in the group process, which entails: 1) balancing the emotional and cognitive components of the learning process; 2) acknowledging and supporting the personal (i.e., individual student's experience) while illuminating the systemic (e.g., interactions among social groups); 3) attending to social relations within the group; 4) utilizing reflection and experience as tools for student-centered learning; and 5) valuing awareness, personal growth, and change as outcomes of the learning process.

Group leaders in this phase need to establish mutually agreed upon group norms for respectful interactions, encourage low-risk self-disclosure, and continually monitor and acknowledge affective responses as students begin their journey toward developing critical consciousness (Bell \& Griffin, 2007). To achieve optimal functioning throughout these first two sessions (and beyond), the group needs to create a safe environment where members are encouraged to share emerging feelings of defensiveness, dissonance, and discomfort that may accompany an exploration of oppression and marginalization in society (Griffin \& Ouellett, 2007).

\subsection{Phase II: Investigation, Examination, and Deconstruction of Societal Narratives about American Indians}

In the second stage, Investigation, examination, and deconstruction of societal narratives about American In 
Table 1. Outline of psychoeducational group format to address marginalization of American Indians.

\begin{tabular}{|c|c|c|c|c|}
\hline Phase & Group Sessions & Purpose (Goals) & Content (Activities) & Process \\
\hline $\begin{array}{l}\text { I. Investigation and } \\
\text { Examination of Social } \\
\text { Justice Principles }\end{array}$ & $\begin{array}{l}\text { 1. Beginnings } \\
\text { 2. Knowledge }\end{array}$ & $\begin{array}{l}\text { Create safe environment } \\
\text { for students to share and } \\
\text { explore social justice issues; } \\
\text { provide foundation of } \\
\text { knowledge on social justice }\end{array}$ & $\begin{array}{l}\text { Familiarize members with } \\
\text { group process; establish } \\
\text { curative factors; connect to } \\
\text { social justice principles in } \\
\text { curriculum unit }\end{array}$ & $\begin{array}{c}\text { Classroom dialogue; } \\
\text { ice breaking; Initial } \\
\text { stage group work }\end{array}$ \\
\hline $\begin{array}{l}\text { II. Investigation, } \\
\text { Examination, and } \\
\text { Deconstruction of } \\
\text { Societal Narratives about } \\
\text { American Indians }\end{array}$ & $\begin{array}{l}\text { 3. Learning and } \\
\text { Unlearning History } \\
\text { 4. Facilitating Perspectives }\end{array}$ & $\begin{array}{l}\text { Investigate and critique } \\
\text { dominant US cultural, } \\
\text { educational, and political } \\
\text { narratives regarding } \\
\text { American Indians }\end{array}$ & $\begin{array}{l}\text { Critically examine and } \\
\text { discuss history textbooks and } \\
\text { sports media (newspapers, } \\
\text { television, online columns, } \\
\text { blogs); create scenarios to } \\
\text { facilitate perspectives }\end{array}$ & $\begin{array}{c}\text { Classroom dialogue; } \\
\text { discourse analysis; } \\
\text { Transition stage } \\
\text { group work }\end{array}$ \\
\hline $\begin{array}{l}\text { III. Synthesis and } \\
\text { Application of Findings }\end{array}$ & $\begin{array}{l}\text { 5. Synthesis and Planning } \\
\text { 6. Presenting Projects }\end{array}$ & $\begin{array}{l}\text { Define and study a problem } \\
\text { based on themes discovered } \\
\text { in Phase I and II; create } \\
\text { presentations to share with } \\
\text { fellow group members for } \\
\text { feedback and support }\end{array}$ & $\begin{array}{l}\text { Plan for social justice project; } \\
\text { implement findings; create } \\
\text { own unique format to present } \\
\text { ideas to fellow students }\end{array}$ & $\begin{array}{l}\text { Oral presentation; } \\
\text { technology use; } \\
\text { Working stage } \\
\text { group work }\end{array}$ \\
\hline $\begin{array}{l}\text { IV. Future Applications } \\
\text { of Social Justice Skills }\end{array}$ & $\begin{array}{l}\text { 7. Processing Projective } \\
\text { Applications of Project } \\
\text { 8. Termination }\end{array}$ & $\begin{array}{l}\text { Develop action plan to } \\
\text { address issues; facilitate } \\
\text { connection of learning } \\
\text { from group to external } \\
\text { world; provide closure to } \\
\text { group members }\end{array}$ & $\begin{array}{l}\text { Provide feedback and support } \\
\text { to fellow group members; } \\
\text { discuss ways to implement } \\
\text { social justice principles in } \\
\text { future endeavors; terminate } \\
\text { group process }\end{array}$ & $\begin{array}{l}\text { Support building; } \\
\text { networking, } \\
\text { Termination stage } \\
\text { group work }\end{array}$ \\
\hline
\end{tabular}

dians, students are directed to pay closer attention to portrayals of American Indians in society. Doing so can help students become critical consumers of their own experiences, while providing ample opportunities for students to contribute to group discussions as group work in this transition stage progresses. Group leaders in this phase need to attend to the affective climate of the group as students learn to work through feelings of guilt and frustration-which can translate into dissonance, conflict and confrontation-as they attempt to make sense of their societal observations. Leaders can facilitate collaborative engagement and group development by validating personal risk taking, encouraging full discussion, and allowing contradictions and tensions to emerge (Bell \& Griffin, 2007). While still observing the norms of respectful interactions set in the initial phase (and modeled by leaders throughout), students can use the group to share and process the reactions they have to their observations of societal portrayals of American Indians. Doing so can help facilitate perspectives that emerge from viewing the world with a more critical eye.

The overarching goal of the two sessions (i.e., Learning and Unlearning History, Facilitating Perspectives) of this second phase is to investigate and critique dominant societal narratives regarding American Indians. Students can be directed to examine institutions in contemporary society (e.g., media, schools, religion, commerce, government) for examples that perpetuate stereotypic portrayals of American Indians. For example, students can look in their history textbooks to examine the ways that American Indians are presented. According to Loewen (2008), American history textbooks utilize the word savage to describe American Indians, while using the word civilized almost exclusively to describe White people, even though anthropological research has demonstrated that American Indians had established a civilized way of life (e.g., agriculture, government, religion) before encounters with explorers (Loewen, 2008). Students can go shopping and observe products that appropriate American Indian culture (e.g., Land O’ Lakes Butter, Jeep Cherokee, Big Chief Sugar; see Merskin, 2001). Additionally, students can observe contemporary media (i.e., internet, newspapers, television) to examine language used to describe American Indians. Newspaper headlines such as “Braves scalp D-backs” (Reuters, 2007) and "Lady Indians on the warpath” (Mitchell, 2009) utilize race-specific language that allows pejorative stereotypes of American nNdians (i.e., bloodthirsty savage) to permeate and negatively distort public perceptions of contemporary American Indian culture.

To facilitate the perspective-taking process within this phase of the group, it is important for students to have a gut-level understanding of this issue, based on the omnipresence and hegemonic nature of this practice. Thus, the following vignette that is taken from a training intervention (Steinfeldt \& Steinfeldt, 2011: p. 3) can be read 
to set the stage for the students' exploration in the second phase:

The crowd roars as the mascot enters the gym. The student section of the East High School Catholics erupts with the anticipated entrance of Father Guido. He is dressed in flowing robes, with golf-ball sized rosary beads flopping around his neck, and a tall cloth hat on his head with the words "CATHOLICS RULE" written on it. He begins his much anticipated halftime routine by tossing fake Eucharistic hosts into the crowd, much to the delight of the fans who gobble them up or toss them back and forth to each other. Throughout the routine, his genuflections are accompanied by his pantomimed crucifix consecrations of the crowd. After his flamboyant flipping of holy water into the crowd, Father Guido goes for the money shot-he grabs the incense urn and completes his frenzied blessing of the crowd before suddenly becoming stoic, dropping to a knee in prayer, then rising to scream in unison with the crowd, "Pope Benedict, lead us to victory!" The fans feel honored to receive Father Guido's blessing, in hopes that it will inspire the crowd to cheer diligently for the Catholics' second half surge to victory.

This example intends to provide students with an understanding about how they might feel if someone took something sacred to them (i.e., Christian religious practices) and used it in such a manner-then told the students that they were honoring them by doing so. This example can facilitate a group discussion on how using American Indians as sports mascots, nicknames, or logos misuses sacred cultural symbols and practices. The continuing use of eagle feathers, dancing, and chanting during mascot performances violates the sanctity of these aspects of American Indian culture while simultaneously continuing to contribute to mainstream America's ignorance of American culture (Staurowsky, 1999). In being subjected to the perspective of American Indians on this issue, students can critically evaluate the nature and function of societal portrayals of American Indians. For other perspective-facilitating examples, see Steinfeldt \& Steinfeldt (2011). These examples highlight the marginalization process to which American Indians are uniquely subjected, but students and leaders can use emerging critical consciousness developed in this phase to make connections to other forms of societal oppression.

\subsection{Phase III: Synthesis and Application of Findings}

In the third phase, Synthesis and application of findings, students can identify and engage in a social justice project based on their experiences and findings in the first two phases of this group. The first session of this phase, Synthesis and Planning, allows each student to choose a social justice activity that the (s) he can actually carry out. If social justice skills are to be fully developed, students need to have advocacy experiences that transform abstract concepts into concrete form (Westheimer \& Kahne, 1998). In this phase, students can use the collaborative learning group process to explore possible advocacy ideas, and they will be encouraged to engage in a project based on whatever level of comfort they possess. For example, a student could join an activist discussion group (e.g., "Say NO to Mascots" on http://www.yahoo.com) that disseminates information daily on current events related to Native-themed mascots, nicknames, and logos. Tapping into the internet skills of many of today's adolescents, a student could create a YouTube video that expresses a perspective highlighting the experience of American Indians subjected to societal marginalization (e.g., a parody on commercial products appropriating American Indian culture). Students could write a letter to FedEx, the naming-rights sponsor of the Washington Redskins football stadium, indicating consumer dissatisfaction and implications of their partnership with an organization with a racialized nickname and logo. There are many additional options students can explore as they prepare to be exposed to the action stage of social justice. Students can use the group to generate ideas and support for their activity as they continue to cultivate their emerging critical consciousness.

The second session of this phase, Presenting Projects, involves students describing the social justice activity they have chosen to engage in. Having completed their chosen activity, students will present a description of their activity so group members can share their reactions to these social justice learning experiences. The group process can allow members to provide and receive feedback that can effectively validate their fledgling social justice experiences. Although rewarding, social justice advocacy can be a draining, exhausting, and isolating experience (Steinfeldt et al., 2012). Thus, a cohesive working group can provide members with emotional support and validation, and the group experience can equip members with skills to develop support systems to use in future social justice endeavors.

\subsection{Phase IV: Future Applications of Social Justice Skills}

In the final phase, Future applications of social justice skills, students continue to process their reactions to their 
own and fellow group members' social justice projects, and carry out the process of termination from the group. The goal of the penultimate session, Processing Projective Applications of Project, is to help students make a connection between what they have experienced in the group and what they can do in the future. In this session, group leaders can assist members in conceptualizing how they will apply the awareness, knowledge, and skills from this group to their life outside of group. Members can use this session to discuss how their experience with exploring American Indian marginalization relates to other examples of oppression and marginalization that they have experienced or envision addressing in the future. By participating in this proposed group, students can build networks and coalitions, and share ways that they can support each other in becoming agents of change.

In the final session, Termination, students will continue to celebrate what they have learned and continue to explore how they are going to use this knowledge in the future. Students are encouraged to explicitly process the termination of the group. Group leaders in this phase encourage members to articulate feelings they may have about the termination process, such as feelings of loss, shared appreciation, and unfinished business they may have with the group (Stockton, Terry, \& Bhusumane, 2007). Given the transformative potential of this type of social justice group, it is important for leaders to validate the growth and development they notice among individual members and within the group as a whole. Students in this final phase can leave the group feeling good about themselves as contributing members of a participatory democracy (Westheimer \& Kahne, 1998) who are beginning to realize how they can turn social justice awareness and knowledge into social justice skills.

\section{Conclusion}

With social justice's emerging prominence as the "fifth force" (e.g., Ratts et al., 2004) in counseling and psychology, educators are called upon to provide opportunities to examine societal injustices so that students can become aware of social justice as a basic value (Portman \& Portman, 2002). "Becoming aware of the various forms of cultural oppression and social injustices that adversely affect the mental health of clients from devalued groups in US society as well as the psychological development of many Western-trained mental health practitioners is an essential component of the process of liberation psychology” (Duran et al., 2008: p. 289). This proposes psychoeducational group curriculum addresses the societal marginalization of American Indians as an example of how to apply social justice principles, specifically to issues related to American Indians but also broadly to other marginalized groups in society. In addition to facilitating attitudinal change, the group experience can help students become empowered to address oppression, injustice, and marginalization across a variety of domains. In addition to cultivating students' emerging social justice skills, this group format has the potential to help current and future professionals and other educators (e.g., teachers, administrators, coaches) familiarize themselves with issues salient to American Indian communities. "An increase in accurate information about Native Americans is viewed as necessary for the achievement of other goals such as poverty reduction, educational advancements, and securing treaty rights” (King et al., 2002: p. 392). By using collaborative engagement within the group setting, educators can address social justice issues that can empower students, teachers, administrators, and others who are interested in eliminating injustices in society.

\section{References}

Adams, M. (2007). Pedagogical Frameworks for Social Justice Education. In M. Adams, L. A. Bell, \& P. Griffin (Eds.), Teaching for Diversity and Social Justice (pp. 20-33). New York: Routledge.

Aldarondo, E. (2007). Advancing Social Justice through Clinical Practice. Manway, NJ: Lawrence Erlbaum Inc.

Alkon, A. H., \& Norgaard, K. M. (2009). Breaking the Food Chains: An Investigation of Food Justice Activism. Sociological Inquiry, 79, 289-305. http://dx.doi.org/10.1111/j.1475-682X.2009.00291.x

American Counseling Association (2001). Resolution: Opposition to Use of Stereotypical Native American Images as Sports Symbols and Mascots. http://aistm.org/2001aca.htm

American Indian Sports Team Mascots (AISTM) (2014). List of Organizations Endorsing Retirement of "Indian” Sports Team Tokens. http://aistm.org/fr.groups.htm

American Psychological Association (2003). Guidelines on Multicultural Education, Training, Research, Practice, and Organizational Change for Psychologists. American Psychologist, 58, 377-402. http://dx.doi.org/10.1037/0003-066X.58.5.377

American Psychological Association (2008). Report of the Task Force on the Implementation of the Multicultural Guidelines. http://www.apa.org/about/governance/council/policy/multicultural-report.pdf

Associated Press (2009). A Darker Side of Columbus Emerges in US Classrooms. 
http://www.usatoday.com/news/education/2009-10-12-columbus-day_N.htm?csp=34

Association for Multicultural Counseling and Development (2009). AMCD Multicultural Counseling Competencies. http://www.amcdaca.org/amcd/competencies.pdf

Bell, L. A. \& Griffin, P. (2007). Designing Social Justice Education Courses. In M. Adams, L. A. Bell, \& P. Griffin (Eds.), Teaching for Diversity and Social Justice (pp. 67-87). New York: Routledge.

Duran, E. (2006). Healing the Soul Wound: Counseling with American Indians and Other Native Peoples. Multicultural Foundations of Psychology and Counseling Series, New York: Teachers College Press.

Duran, E., Firehammer, J., \& Gonzalez, J. (2008). Liberation Psychology as the Path toward Healing Cultural Soul Wounds. Journal of Counseling and Development, 86, 288-295. http://dx.doi.org/10.1002/j.1556-6678.2008.tb00511.x

Fenelon, J. V. (1999). Indian Icons in the World Series of Racism: Institutionalization of the Racial Symbols of Wahoos and Indians. Research in Politics and Society, 6, 25-45.

Fox, D. R. (2003). Awareness Is Good, but Action Is Better. The Counseling Psychologist, 31, 299-304. http://dx.doi.org/10.1177/0011000003031003005

Friere, P. (1970). The Pedagogy of the Oppressed. New York: Continuum.

Fryberg, S. A., Markus, H. R., Oyserman, D., \& Stone, J. M. (2008). Of Warrior Chiefs and Indian Princesses: The Psychological Consequences of American Indian Mascots. Basic and Applied Social Psychology, 30, 208-218. http://dx.doi.org/10.1080/01973530802375003

Goodman, L. A., Liang, B., Helms, J. E., Latta, R. E., Sparks, E., \& Weintraub, S. R. (2004). Training Counseling Psychologists as Social Justice Agents: Feminist and Multicultural Principles in Action. The Counseling Psychologist, 32, $793-837$. http://dx.doi.org/10.1177/0011000004268802

Goodman, R. D., \& West-Olatunji, C. A. (2009). Applying Critical Consciousness: Culturally Competent Disaster Response Outcomes. Journal of Counseling \& Development, 87, 458-465. http://dx.doi.org/10.1002/j.1556-6678.2009.tb00130.x

Griffin, P., \& Ouellett, M. L. (2007). Facilitating Social Justice Education Courses. In M. Adams, L. A. Bell, \& P. Griffin (Eds.), Teaching for Diversity and Social Justice (pp. 89-113). New York: Routledge.

Grounds, R. (2001). Tallahassee, Osceola and the Hermeneutics of American Place-Names. Journal of the American Academy of Religion, 69, 287-322. http://dx.doi.org/10.1093/jaarel/69.2.287

Indian Health Service, IHS (2011). IHS Fact Sheets: Behavioral Health. http://info.ihs.gov/Bhealth.asp

Kim-Prieto, C., Goldstein, L. A., Okazaki, S., \& Kirschner, B. (2010). Effect of Exposure to an American Indian Mascot on the Tendency to Stereotype a Different Minority Group. Journal of Applied Social Psychology, 40, 534-553. http://dx.doi.org/10.1111/j.1559-1816.2010.00586.x

King, C. R., Davis-Delano, L., Staurowsky, E. J., \& Baca, L. (2006). Sports Mascots and the Media. In G. Tennenbaum, \& R. C. Eklund (Eds.), Handbook of Sport Psychology (3rd ed., pp. 559-575). Hoboken, NJ: Wiley and Sons.

King, C. R., Staurowsky, E. J., Baca, L., Davis, L. R., \& Pewewardy, C. (2002). Of Polls and Prejudice: Sports Illustrated’s Errant "Indian Wars”. Journal of Sport \& Social Issues, 26, 381-402. http://dx.doi.org/10.1177/0193732502238255

Loewen, J. (2008). Lies My Teacher Told Me: Everything Your American History Textbook Got Wrong (2nd ed.). New York: W. W. Norton \& Company.

MacNair-Semands, R. R. (2007). Attending to the Spirit of Social Justice as an Ethical Approach to Group Therapy. International Journal of Group Psychotherapy, 57, 61-66. http://dx.doi.org/10.1521/ijgp.2007.57.1.61

Merskin, D. (2001). Winnebagos, Cherokees, Apaches and Dakotas: The Persistence of Stereotyping of American Indians in American Advertising Brands. The Howard Journal of Communications, 12, 159-169.

http://dx.doi.org/10.1080/106461701753210439

Mitchell, J. (2009). Lady Indians on the Warpath after Rolling over Seahawks. http://www.sussexcountian.com/sports/x497782934/Lady-Indians-on-the-warpath-after-rolling-over-Seahawks

Neville, H. A., Lilly, R. L., Duran, G., Lee, R. M., \& Browne, L. (2000). Construction and Initial Validation of the Color-Blind Racial Attitudes Scale (CoBRAS). Journal of Counseling Psychology, 47, 59-70. http://dx.doi.org/10.1037/0022-0167.47.1.59

Olson, L. M., \& Wahab, S. (2006). American Indians and Suicide: A Neglected Area of Research. Trauma, Violence and Abuse, 7, 19-33. http://dx.doi.org/10.1177/1524838005283005

Pewewardy, C. D. (1991). Native American Mascots and Imagery: The Struggle of Unlearning Indian Stereotypes. Journal of Navajo Education, 9, 19-23.

Pieterse, A. L., Evans, S. A., Risner-Butner, A., Collins, N. M., \& Mason, L. B. (2009). Multicultural Competence and Social Justice Training in Counseling Psychology and Counselor Education. The Counseling Psychologist, 37, 93-115. http://dx.doi.org/10.1177/0011000008319986 
Portman, T. A. A., \& Portman, G. L. (2002). Empowering Students for Social Justice: A Structured Group Approach. Journal for Specialists in Group Work, 27, 16-31. http://dx.doi.org/10.1177/0193392202027001003

Ratts, M. J., DeKruyf, L., \& Chen-Hayes, S. F. (2007). The ACA Advocacy Competencies: A Social Justice Advocacy Framework for Professional Counselors. Professional School Counseling, 11, 90-97. http://dx.doi.org/10.5330/PSC.n.2010-11.90

Ratts, M., D’Andrea, M., \& Arredondo, P. (2004). Social Justice Counseling: Fifth Force in Counseling. Counseling Today, 47, 28-30.

Reuters (2007). Dream Day for Owings as D-Backs Scalp Braves. http://www.reuters.com/article/idUSB13907520070819

Russel, S. (2003). Ethics, Alterity, Incommensurability, Honor. Ayaangwaamizin: The International Journal of Indigenous Philosophy, 3, 31-54.

Smith, L. C., \& Shin, R. Q. (2008). Social Privilege, Social Justice and Group Counseling: An Inquiry. The Journal for Specialists in Group Work, 33, 351-366. http://dx.doi.org/10.1080/01933920802424415

Staurowsky, E. J. (1999). American Indian Imagery and the Miseducation of America. Quest, 51, 382-392. http://dx.doi.org/10.1080/00336297.1999.10491693

Staurowsky, E. J. (2004). Privilege at Play: On the Legal and Social Fictions that Sustain American Indian Sport Imagery. Journal of Sport and Social Issues, 28, 11-29. http://dx.doi.org/10.1177/0193732503261148

Steele, J. M. (2008). Preparing Counselors to Advocate for Social Justice: A Liberation Model. Counselor Education and Supervision, 48, 74-85. http://dx.doi.org/10.1002/j.1556-6978.2008.tb00064.x

Steinfeldt, J. A., \& Steinfeldt, C. M. (2012). Multicultural Training Intervention to Address Native American Stereotypes. Counselor Education and Supervision, 51, 17-32.

Steinfeldt, J. A., \& Wong, Y. J. (2010). Multicultural Training on American Indian Issues: Testing the Effectiveness of an Intervention to Change Attitudes toward Native-Themed Mascots. Cultural Diversity and Ethnic Minority Psychology, 16, 110-115. http://dx.doi.org/10.1037/a0018633

Steinfeldt, J. A., Foltz, B. D., Kaladow, J. K., Carlson, T., Pagano, L., Benton, E., \& Steinfeldt, M. C. (2010). Racism in the Electronic Age: Role of Online Forums in Expressing Racial Attitudes about American Indians. Cultural Diversity and Ethnic Minority Psychology, 16, 362-371. http://dx.doi.org/10.1037/a0018692

Steinfeldt, J. A., Foltz, B. D., LaFollette, J. R., White, M. R., Wong, Y. J., \& Steinfeldt, M. C. (2012). Perspectives of Social Justice Activists: Advocating against Native-Themed Mascots, Nicknames and Logos. The Counseling Psychologist, 40, 326-362. http://dx.doi.org/10.1177/0011000011411736

Stockton, R. A., Terry, L., \& Bhusumane, D. (2007). Fundamentals of Group Work. In J. Gregoire, \& C. M. Jungers (Eds.), The Counselor's Companion: What Every Beginning Counselor Needs to Know (pp. 274-275). Mahwah, NJ: Lawrence Erlbaum Associates.

Vera, E. M., \& Speight, S. L. (2003). Multicultural Competencies, Social Justice and Counseling Psychology: Expanding Our Roles. The Counseling Psychologist, 31, 253-272. http://dx.doi.org/10.1177/0011000003031003001

Westheimer, J., \& Kahne, J. (1998). Education for Action: Preparing Youth for a Participatory Democracy. In W. Ayers, J. A. Hunt, \& T. Quinn (Eds.), Teaching for Social Justice (pp. 1-20). New York: The New Press.

Williams, D. M. (2007). Where's the Honor? Attitudes toward the “Fighting Sioux” Nickname and Logo. Sociology of Sport Journal, 24, 437-456. 
Scientific Research Publishing (SCIRP) is one of the largest Open Access journal publishers. It is currently publishing more than 200 open access, online, peer-reviewed journals covering a wide range of academic disciplines. SCIRP serves the worldwide academic communities and contributes to the progress and application of science with its publication.

Other selected journals from SCIRP are listed as below. Submit your manuscript to us via either submit@scirp.org or Online Submission Portal.
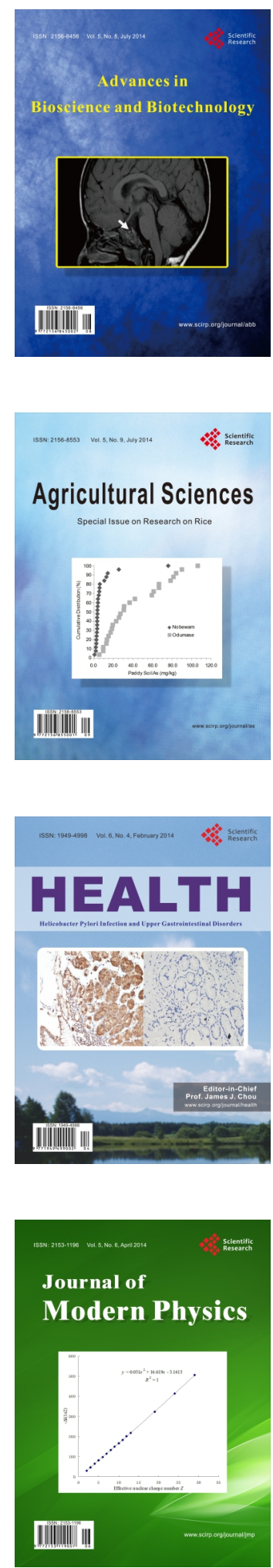
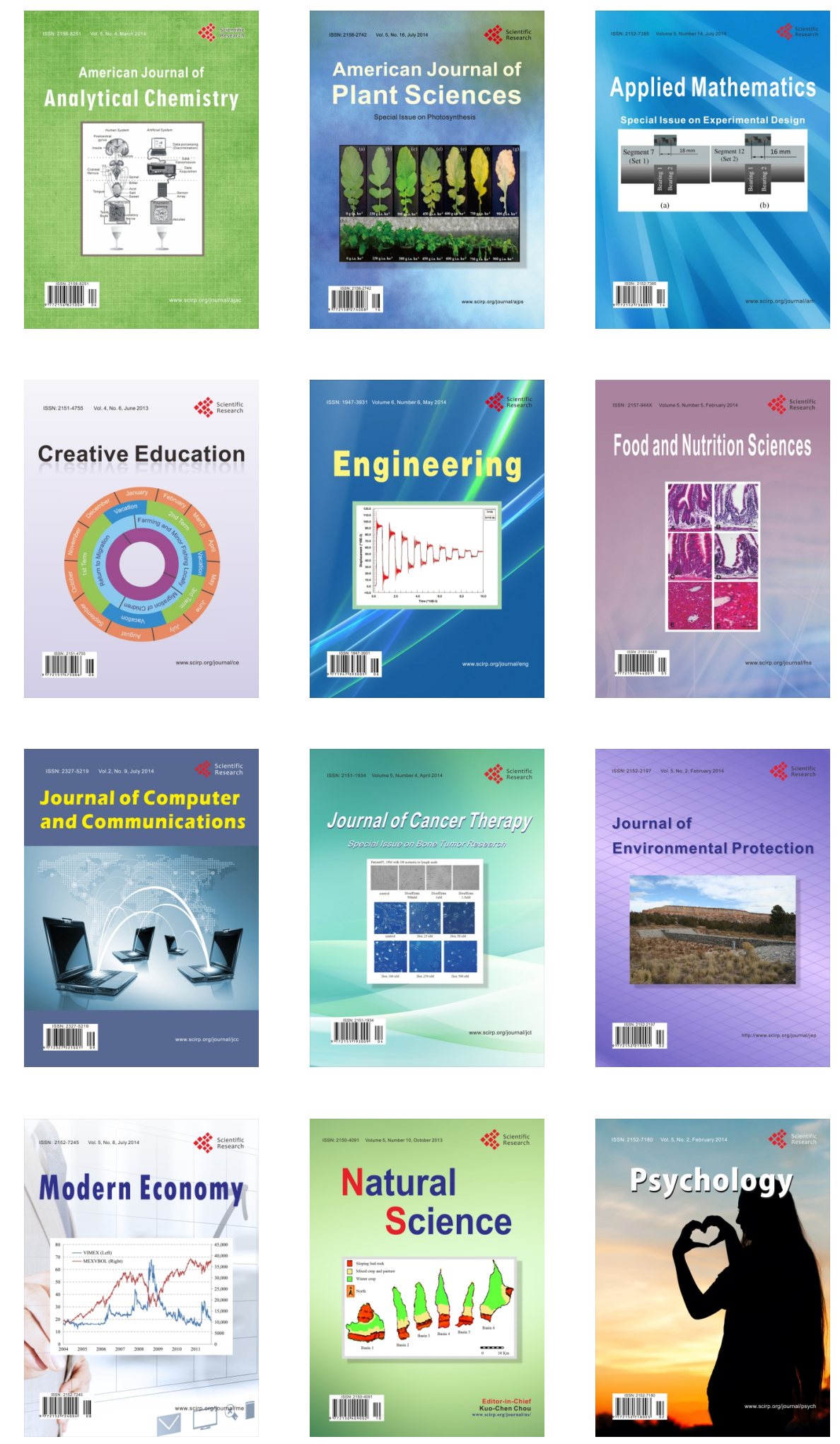